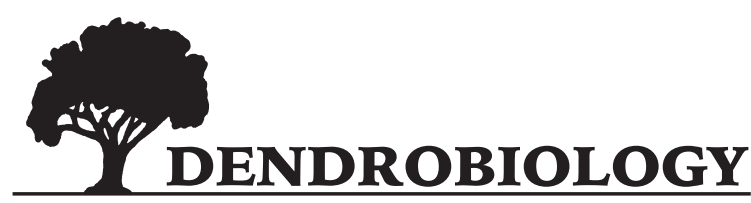

2014, vol. 72, 163-176

http://dx.doi.org/10.12657/denbio.072.014

Wojciech Kraj

\section{Proteolytic activity and nitrogen remobilisation in senescing leaves of phenological forms of Fagus sylvatica}

Received: 18 November 2013; Accepted: 20 May 2014

\begin{abstract}
Leaf senescence allows plants to remobilise and use the same nitrogen repeatedly and is closely linked to autumn phenology. The timing of leaf senescence affects the growth rate and survival of trees due to the association between senescence and the remobilisation of nutrients, particularly nitrogen. The present study compares protein degradation dynamics and nitrogen remobilisation in early, intermediate and late phenological forms of beech trees (Fagus sylvatica L.). Specimens of phenological forms were marked and examined in 2005 and 2008. Leaf samples were collected from August to October during each of these years, and a biochemical analysis and a determination of proteolytic enzyme activity were conducted. The early phenological form showed protein degradation with three clearly indicated phases, whereas in the late form, protein degradation was stable with a constant decrease. The phenological forms differed significantly in their $\mathrm{C} / \mathrm{N}$ ratios, which increased from approximately 20 in August to 37.5, 35 and 32 for the early, intermediate and late forms, respectively, at the end of leaf senescence. The date of the sudden drop in temperature had a decisive effect on the beginning of leaf senescence. Temperature has a greater effect on protein degradation and the protein and nitrogen resorption efficiency in the early form than in the late form. The trees that began to senesce the earliest exhibited the highest resorption of nitrogen compounds. Senescence led to an increase in proteolytic activity. Aminopeptidase activity was highest at the beginning of senescence, while endo- and carboxypeptidase activity was highest in the middle of senescence. The early form had the highest activity levels for all peptidase types. These results indicate that beech trees that differ in their autumn senescence timing display different nitrogen remobilisation efficiencies. This efficiency depended on the length of leaf senescence, peptidase activity and the sensitivity of particular phenological forms to temperature changes.
\end{abstract}

Additional key words: beech, leaf senescence, peptidase, proteins, phenology

Address: W. Kraj, Department of Forest Pathology, Mycology and Tree Physiology, Agricultural University in Cracow, Al. 29-Listopada 46, 31-425 Cracow, e-mail: rlkraj@cyf-kr.edu.pl

\section{Introduction}

The European beech (Fagus sylvatica L.) is an important deciduous tree species in Europe. It occupies various habitats, ranging from the mountainous re- gions of southern and eastern Europe to the lowlands of central Europe (Fang and Lechowicz 2006; Paule 1995). The wide range of climatic conditions that occur in these locations causes great variability in the beech populations. Early and late beech forms can 
be classified on the basis of their phenological traits. These phenotypes have distinctive physiological and morphological features, including differences in the timing of spring bud break and the onset of leaf senescence, frost resistance dynamics and leaf size (Dolnicki and Kraj 2001; Chmura and Rożkowski 2002; Stachak 1965). The difference in occurrence time for the spring and autumnal phenological phases of early and late beeches can be as much as 20 days (Chmura and Rożkowski 2002; Dolnicki and Kraj 2001). Although there are many reports on the spring phenology of beech forms (Chmura and Rożkowski 2002; Škvareninová and Snopková 2011), investigations on autumnal leaf senescence, especially its biochemical basis, have rarely been reported. To date, most studies have shown that the timing of leaf senescence or bud set is consistent from year to year; this finding demonstrates that there is a high degree of genetic control over these characteristics (Vitasse et al. 2009; Howe et al. 2003). However, the end of the growing season is difficult to record precisely due to the effects of environmental conditions such as low temperature (Vitasse et al. 2009).

Senescence, the final phase of leaf development, leads to leaf death and fall (Smart 1994). Leaf senescence is highly coordinated and genetically controlled. This phase involves decreased photosynthetic activity in the leaves and the degradation of chloroplasts and cellular macromolecules (Buchanan-Wollaston et al. 2003; Gan 2003; Lin and Wu 2004; Quirino et al. 2000). The primary function of natural senescence in leaves is to remobilise and recycle cellular macromolecules (Aerts 1996; Himelblau and Amasino 2001). The redistribution of nutrients within the plant, which is accompanied by a build-up of carbon and nitrogen reserves, may be the main determinant of tree longevity (Guiboileau et al. 2010).

Nitrogen is the most important nutrient compound that is remobilised during senescence. It is a major growth-limiting factor in natural forest ecosystems and influences the growth patterns of beech trees (Marschner 1995; Rennenberg et al. 1998). Because nitrogen availability is very limited in forest soils, trees require an efficient mechanism for the assimilation, storage and remobilisation of the organic and inorganic forms of nitrogen to ensure optimal growth conditions (Couturier et al. 2010). The duration of leaf senescence and the tight coordination of its onset are important for the efficiency of nitrogen remobilisation and storage for the next year's growth. The adaptive value of leaf senescence timing is clear; if leaf senescence begins too early, the growth period will be shortened and the carbon gained through photosynthesis will decrease, whereas if senescence occurs too late, the green leaves will be killed by frost and the leaf nitrogen will be lost (Fracheboud et al. 2009). Seasonal nitrogen recycling constitutes the adaptation of plants to the climate and to conditions in which nutrients are often growth limiting (Cooke and Weih 2005). Autumnal nutrient resorption in temperate hardwood forests typically leads to the resorption of half (Aerts 1996) or more (Duchesne et al. 2001; Cote et al. 2002) of the nitrogen that is present in leaves before abscission.

Over $50 \%$ of the nitrogen in photosynthetically active tissues is found in soluble (Calvin cycle) and insoluble (thylakoid) chloroplast proteins (Feller and Fischer 1994; Gan and Amasino 1997). The amino acids produced during protein degradation are released, transported and stored in protein form within other parts of the plant (Diaz et al. 2005). In broadleaf trees, these proteins are stored in specialised trunk and root tissues (Coleman et al. 1993; Millard and Grelet 2010). Plant proteolysis is a complex process that involves a number of enzymes. These enzymes can be classified into specific groups depending on the position of the cleaved peptide bond within the polypeptide chain. Endopeptidases attack peptide bonds within polypeptides, whereas exopeptidases cleave amino acids from either the $\mathrm{N}$-terminus (aminopeptidases) or C-terminus (carboxypeptidases) of the protein (Brouquisse et al. 2001; Feller and Fischer 1994; Huffaker 1990).

The patterns of peptidase activity that are associated with leaf senescence vary considerably depending on their type, their location in the leaf cells and the plant species. Because most of the nitrogen present in mesophyll cells is located within chloroplasts, the activity of chloroplast peptidases plays a central role in the mobilisation of this macroelement (Hortensteiner and Feller 2002). Endopeptidases are essential for the first stages of peptide bond cleavage and are therefore important for the initiation of the catabolism of chloroplast proteins, primarily $\mathrm{Ru}-$ bisco (Hortensteiner and Feller 2002). Additionally, aminopeptidase activity in chloroplasts reportedly contributes to the complete degradation of stromal proteins by degrading the peptides generated by endopeptidase activity (Roulin and Feller 1998). Carboxypeptidases, which have not been detected in intact plastids (Feller and Fischer 1994), play a role in the degradation of plastid proteins in lytic vacuoles (Hortensteiner and Feller 2002; Yang et al. 2004).

Many important questions concerning autumn leaf senescence in beech trees must be answered: a) how is the senescence process executed and what is the impact of environmental factors on the onset of this process; b) what are the biochemical and molecular bases of leaf senescence; $c$ ) what is the timetable of biochemical events during beech leaf senescence and d) what is the effect of the phenological form of beech on the course of leaf senescence.

The primary problem that affects tree growth is the timing and extent to which nutrients, particularly 
nitrogen, are remobilised in the leaf. It is important to understand how the timing of autumnal senescence affects the proportion of protein and nitrogen resorption. To address these questions, three groups of beech individuals with different autumn phenology times were selected. These plants were examined to a) compare the protein degradation dynamics during autumnal leaf senescence in phenological forms of beech trees, b) determine the nitrogen remobilisation efficiency in these forms and c) determine the activity profiles of leaf peptidases with respect to nitrogen recycling in naturally senescing leaves.

\section{Materials and Methods}

\section{Plant material}

This study was conducted in an experimental plot (approx. $100 \times 50 \mathrm{~m}$ ) that was established in the Krzeszowice Forest District (geographical coordinates: $\left.50^{\circ} 06^{\prime} 28^{\prime \prime} \mathrm{N}, 1^{\circ} 41^{\prime} 07^{\prime \prime} \mathrm{E}\right)$. In the plot, soil acidity exhibited low variability (mean $\mathrm{pH}_{\mathrm{KCl}} \pm \mathrm{SD}=$ $6.54 \pm 0.2$ ), whereas nitrogen availability exhibited higher variability $(0.29 \% \pm 0.11)$. Between 2004 and 2008, approximately 20015 -year-old beeches were visually scored for autumn senescence. Specimens of early, intermediate and late phenological forms were selected and marked on October 07, 2004, when it was possible to distinguish the senescence stages of the trees, using the modified scale of autumnal phenological stages according to Stachak (1965). The specimens marked as early, intermediate and late forms displayed $50 \%, 20 \%$ and $5-10 \%$ discoloured leaves in their crowns, respectively. The selection of individuals and their assignment to the relevant phenological form was confirmed during subsequent years of observations. Three groups of individuals that showed differences in their senescence start data were thereby distinguished from one another. Fifteen individuals were randomly chosen from each group. Leaves of approximately the same size were collected from sunlit shoots of each individual in 2005 and 2008. The samples were collected on August 20, September 3, September 10, September 18, September 27, October 05, October 13 and October 20 at approximately 9-11 am. The leaf collection was conducted until maximum leaf fall. All leaves were collected from several neighbouring shoots on the same branch under uniform sun exposure on the south side of the crown. The leaves were stored on ice immediately after sampling; later, they were ground in liquid nitrogen and stored at $-80^{\circ} \mathrm{C}$. For dry weight measurement, $100 \mathrm{mg}$ of ground leaves was dried for 72 hours at $70^{\circ} \mathrm{C}$ until a constant weight was reached, and this weight was recorded.

On the basis of an earlier analysis (data not shown), the mature leaves collected on August 20 provided good estimates of the maximum protein and total $\mathrm{N}$ content because the maximum protein concentration in beech leaves from southern Poland was found to be maintained until the second half of August, after which the value begins to decrease.

\section{Biochemical analysis}

\section{Photosynthetic pigment determination}

To estimate the chlorophyll content, $50 \mathrm{mg}$ of leaf powder was placed in $6 \mathrm{ml}$ of cold $80 \%$ acetone $(\mathrm{pH}$ 7.8). The samples were shaken for 1 hour at $4^{\circ} \mathrm{C}$ and centrifuged, and the absorbance of the leaf extracts was measured on a UV-VIS spectrophotometer (Thermo Fisher Scientific, Waltham, MA, USA) at 663 and $646 \mathrm{~nm}$. The chlorophyll concentrations were calculated using the Lichtenthaler and Wellburn (1983) formulae and are expressed in mg/g dry weight.

\section{Total nitrogen and carbon analysis}

A $100 \mathrm{mg}$ sample of ground leaf powder was dried. The samples were combusted at $1350^{\circ} \mathrm{C}$. Carbon content were measured by infrared absorption, while nitrogen was determined by thermal conductivity using a LECO CNS 2000 elemental analyser (LECO, St. Joseph, MI, USA).

\section{Determination of soluble and insoluble proteins}

Soluble proteins were extracted from approximately $50 \mathrm{mg}$ of leaf powder in Tris- $\mathrm{HCl}$ buffer $(\mathrm{pH}$ 7.5) containing $1 \mathrm{mM}$ EDTA (pH 8), $10 \mathrm{mM} \mathrm{MgCl}_{2}$ and $14 \mathrm{mM} \beta$-mercaptoethanol. The water-soluble protein content of the supernatant was determined, and the pellets were incubated for $24 \mathrm{~h}$ at room temperature in Tris- $\mathrm{HCl}$ buffer containing $0.1 \%$ SDS to extract water-insoluble proteins (SDS-soluble proteins) (Kraj and Grad 2013). The protein concentrations of the samples were estimated using the Bradford method (1976) with bovine serum albumin as a standard.

\section{Amino acid determination}

For the amino acid determination, $50 \mathrm{mg}$ of leaf powder was homogenised in $3 \%$ sulphosalicylic acid for 1 hour, and the samples were centrifuged. Aliquots $(100 \mu \mathrm{l})$ of leaf extracts were used for amino acid determination using the ninhydrin method, and glycine was used as a standard (Yokoyama and Hiramatsu 2003).

\section{Proteolytic activity of beech leaves}

\section{Protein extraction}

The peptidase activity of the senescing leaves collected in 2008 was analysed as follows. Soluble proteins were extracted from each leaf powder sample 
with cold $100 \mathrm{mM}$ phosphate buffer $(\mathrm{pH} 7.8)$ (1:10, $\mathrm{w} / \mathrm{v})$ containing $0.5 \%$ Triton X-100, $8 \%(\mathrm{w} / \mathrm{v})$ insoluble polyvinylpolypyrrolidone (PVPP) and $10 \mathrm{mM}$ $\beta$-mercaptoethanol (Sigma, St Louis, MO, USA), and the homogenate was centrifuged at $15,000 \mathrm{rpm}$ for 15 minutes. The resulting supernatant was desalted by centrifugation through Sephadex G-25 Superfine columns (Sigma, St. Louis, MO, USA) that had been equilibrated with $100 \mathrm{mM}$ phosphate buffer $(\mathrm{pH} 7.8)$ containing $10 \mathrm{mM} \beta$-mercaptoethanol. All extraction steps were performed at $0-4^{\circ} \mathrm{C}$.

\section{Peptidase activity determination}

The supernatant from the protein extraction step was used to determine the aminopeptidase, carboxypeptidase and endopeptidase activities. The aminopeptidase activity was spectrophotometrically determined using $2 \mathrm{mM}$ L-leu-p-nitroanilide (Sigma, St Louis, MO, USA) in $50 \mathrm{mM}$ phosphate buffer ( $\mathrm{pH}$ 6.7) with $2 \%$ DMSO as the substrate. Forty microlitres of extract was mixed with $1 \mathrm{ml}$ of substrate and incubated at $37^{\circ} \mathrm{C}$ for $1 \mathrm{~h}$. The reaction was stopped by adding $0.5 \mathrm{ml}$ of perchloric acid. The reaction mixture was centrifuged at 10,000 rpm for 10 minutes, and its absorbance was measured at $410 \mathrm{~nm}$ with a Synergy 2 microplate reader (Biotek, Winooski, VT, USA). One unit of enzyme activity was defined as one unit of change in absorbance per hour at $37^{\circ} \mathrm{C}$. Carboxypeptidase assays were performed with $2 \mathrm{mM}$ N-carbobenzoxy-L-phenylalanine-L-alanine (Sigma, St Louis, MO, USA) in $25 \mathrm{mM}$ citric acid-phosphate buffer ( $\mathrm{pH}$ 5.0) containing 2\% DMSO as the substrate. A $150-\mu$ l aliquot of extract was mixed with $900 \mu \mathrm{l}$ of substrate solution and incubated at $37^{\circ} \mathrm{C}$ for $1 \mathrm{~h}$. The reaction was stopped by adding $1 \mathrm{ml}$ of $15 \%$ trichloroacetic acid (TCA). After standing on ice for 10 minutes, the samples were centrifuged at $16,000 \mathrm{rpm}$ for $10 \mathrm{~min}$, and the liberated $\alpha$-amino acids were assayed by the ninhydrin meth- od (Yokoyama and Hiramatsu 2003). The endopeptidase activity was measured with $1 \%$ azocasein in $25 \mathrm{mM}$ citric acid-phosphate buffer ( $\mathrm{pH}$ 5.7) containing $0.1 \% \beta$-mercaptoethanol or in $25 \mathrm{mM}$ phosphate buffer $(\mathrm{pH} 7.5)$. The assay mixture contained $1 \mathrm{ml}$ of substrate solution, $200 \mu \mathrm{l}$ of extract and $800 \mu \mathrm{l}$ of $\mathrm{H}_{2} \mathrm{O}$. After 4 hours of incubation at $37^{\circ} \mathrm{C}$, any undigested azocasein and large fragments of the protein were precipitated with $1 \mathrm{ml}$ of cold $15 \%$ TCA for 1 hour. The samples were centrifuged at 13,000 rpm for 10 minutes, and the absorbance of the supernatant was determined at $405 \mathrm{~nm}$. One unit of enzyme activity was defined as one unit of change in absorbance per 4 hours at $37^{\circ} \mathrm{C}$.

\section{Data analysis}

Temporal differences in the photosynthetic pigment content, protein content and enzymatic activity in leaves from the different phenological forms of beech trees were evaluated for various experimental times using repeated measures ANOVA (RM-ANOVA); Fisher's LSD test was used as a posthoc test. Differences were considered significant at $\mathrm{P}<0.05$. The data were tested for homogeneity of variance using Bartlett's test (Sokal and Rohlf 1995). All statistical analyses were conducted using Statistica software, version 10.0 (StatSoft Inc., Tulsa, OK, USA). Correlation analyses were conducted to examine the relationships among 1) temperature and nitrogen content and 2) protease activity and biochemical characteristics (chlorophyll, soluble and insoluble protein, amino acid and nitrogen contents, and the $\mathrm{C} / \mathrm{N}$ ratio) of senescing leaves from different phenological forms of beech trees. The degree of protein remobilisation was calculated using the protein resorption efficiency (PRE), which is defined as the proportion of proteins resorbed to perennial plant parts before leaf abscission.
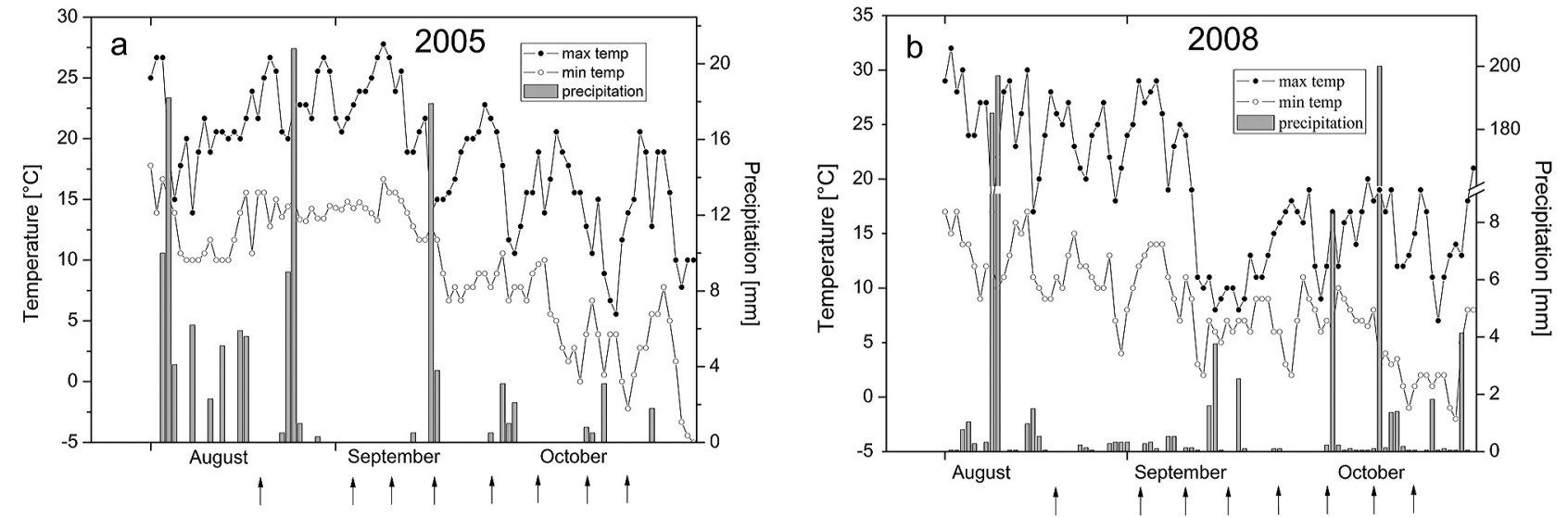

Fig. 1. Weather conditions during the 2005 and 2008 sampling periods. The grey bars represent the millimetres of precipitation per day. The lines correspond to the maximum and minimum temperatures $\left({ }^{\circ} \mathrm{C}\right)$. The arrows indicate the sampling dates 
Table 1. The results of the repeated measures ANOVA: A) phenological form and year effect on chlorophyll, soluble and insoluble proteins, amino acids, nitrogen content, $\mathrm{C} / \mathrm{N}$ ratio and $\mathrm{B}$ ) phenological form effect on proteinase activity in senescing leaves of beech trees (Fagus sylvatica L.)

\begin{tabular}{|c|c|c|c|}
\hline Effect & $\mathrm{df}$ & F-value & Probability \\
\hline \multicolumn{4}{|c|}{ Biochemical compounds* } \\
\hline \multicolumn{4}{|c|}{ Chlorophyll a+b } \\
\hline Phenological form & 2 & 10.62 & $<0.001$ \\
\hline Year & 1 & 7.33 & 0.009 \\
\hline \multicolumn{4}{|c|}{ Soluble proteins } \\
\hline Phenological form & 2 & 580.02 & $<0.0001$ \\
\hline Year & 1 & 691.66 & $<0.0001$ \\
\hline \multicolumn{4}{|c|}{ Insoluble proteins } \\
\hline Phenological form & 2 & 103.32 & $<0.0001$ \\
\hline Year & 1 & 15.46 & $<0.001$ \\
\hline \multicolumn{4}{|c|}{ Amino acids } \\
\hline Phenological form & 2 & 28.52 & $<0.01$ \\
\hline Year & 1 & 0.06 & 0.805 \\
\hline \multicolumn{4}{|c|}{ Nitrogen } \\
\hline Phenological form & 2 & 8.20 & 0.008 \\
\hline Year & 1 & 5.39 & 0.024 \\
\hline \multicolumn{4}{|c|}{$\mathrm{C} / \mathrm{N}$ ratio } \\
\hline Phenological form & 2 & 9.41 & 0.0003 \\
\hline Year & 1 & 5.79 & 0.02 \\
\hline \multicolumn{4}{|c|}{ Proteinase activity (phenological form effect) } \\
\hline Aminopeptidase & 2 & 3.89 & 0.033 \\
\hline Carboxypeptidase & 2 & 4.37 & 0.023 \\
\hline Endopeptidase, pH 5.7 & 2 & 5.50 & 0.01 \\
\hline Endopeptidase, pH 7.5 & 2 & 79.20 & $<0.0001$ \\
\hline
\end{tabular}

* Phenological form $\times$ year interaction was insignificant in all analysis

\section{Results}

Our observations of the percentage of discoloured leaves and the changing dynamics of leaf colours between 2005 and 2008 made it possible to determine the dates for the autumnal stages of senescence in specimens belonging to early, intermediate and late phenological forms. The climatic conditions during the sampling periods are shown in Fig. 1a and b. An analysis of changes in the maximum and minimum temperatures showed that a milder drop in temperature occurred in 2005 than in 2008, and two stages of the temperature course were observed. During the first stage, the temperature was stable until approximately September 12, 2005, and September 5, 2008; there was then a significant drop in temperature. The difference in the average temperatures during the sampling period between 2005 and 2008 was approximately $0.7^{\circ} \mathrm{C}$.

The appearance of the autumnal phenological stages was related to changes in the temperature. In 2005, the beech specimens showed a later onset (by approximately 7-10 days) of autumnal leaf senescence in comparison to 2008 . The length of the se- nescence period from the first visual indicators until the beginning of leaf fall depended on the phenological form; the lengths of this period were 15, 13 and 10 days in 2005 and 14, 13 and 11 days in 2008 for the early, intermediate and late forms, respectively.

Significant differences occurred in the levels of chlorophyll, soluble and insoluble proteins, amino acids and nitrogen and in the $\mathrm{C} / \mathrm{N}$ ratio among the phenological forms of beech $(\mathrm{P}<0.001$ for all analysed compounds) (Tab. 1). These differences allowed for the characterisation of the biochemical features of the senescing leaves.

\section{Chlorophyll content as a biochemical marker of senescence}

In this study, chlorophyll was used as a biochemical marker of leaf senescence. RM-ANOVA analysis demonstrated an overall effect of phenological form on chlorophyll content during both sampling periods $(\mathrm{P}<0.001$, Tab. 1). Prior to the onset of senescence (August 20), late form specimens contained significantly (on average 10\%) more total chlorophyll than early form specimens (Fig. 2). The chlorophyll content of the leaves was stable until approximately September 3 (2008) to September 10 (2005) for both the early and intermediate forms and until September 18 (2005 and 2008) for the late form. Chlorophyll began to degrade after these dates, and the rate depended on the phenological form of the trees and the temperature distribution (Figs. 1a-b and 2). A significant effect of year $(\mathrm{P}<0.01)$ on the chlorophyll content was found for the period starting from September 10 to October 05 for both the early and intermediate forms and from September 27 to October 20 for the late form, i.e., after the period during which a significant drop in temperature occurred. The length of the chlorophyll degradation stage was approximately 47 days for the early form, 40 days for the intermediate form and 32 days for the late form. From the beginning of senescence until the last sampling date, the chlorophyll content decreased by an average of $83 \%$ and $74 \%$ for 2005 and 2008, respectively.

\section{Protein and amino acid content dynamics}

The protein extraction method used in this study divided proteins into water-soluble and water-insoluble fractions (SDS-soluble proteins). The initial insoluble protein content was significantly higher (approximately 30\%) than the initial soluble protein content $(\mathrm{P}<0.001)$. Except during the initial phase of leaf senescence, the late form exhibited significantly higher contents of soluble and insoluble pro- 

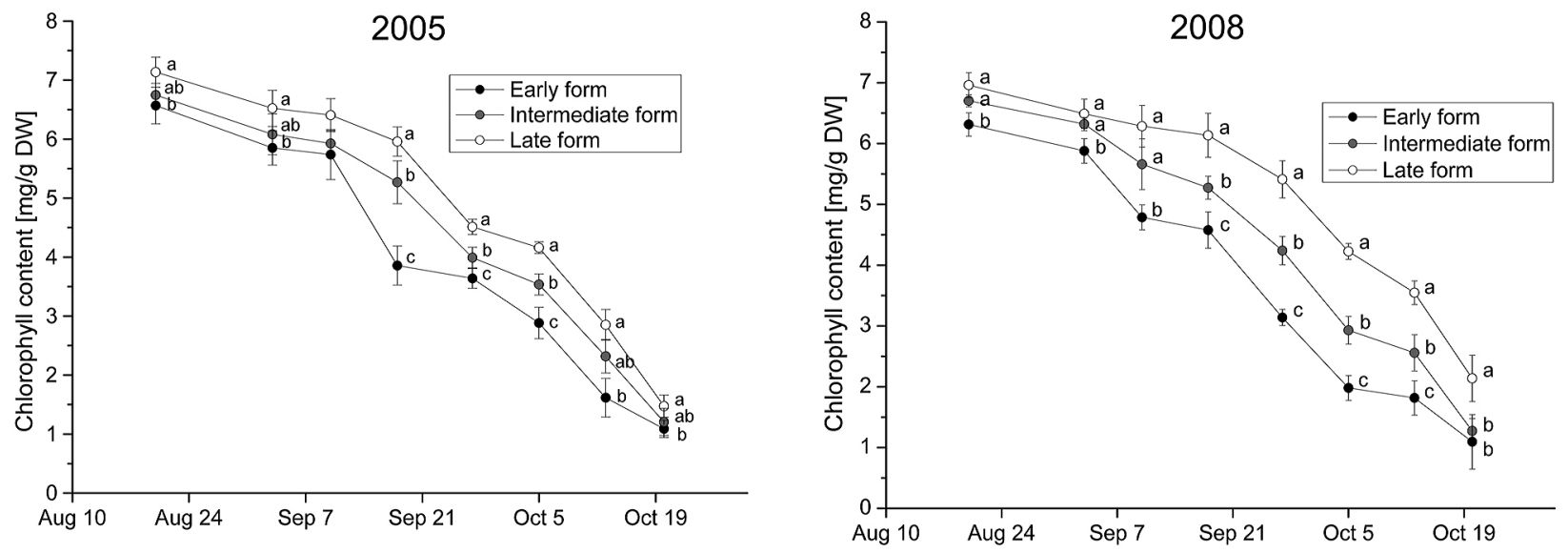

Fig. 2. Changes in the chlorophyll content of autumn leaves from different phenological forms of beech trees (Fagus sylvatica L.). Each point is the mean of 15 measurements ( \pm SD). Means denoted by different letters are significantly different at $\mathrm{P}<0.05$

tein than the early form $(\mathrm{P}<0.0001)$ (Tab. 1, Fig. $3 a-d)$. During senescence, the levels of both soluble and insoluble proteins decreased slightly until an intense degradation of the photosynthetic pigments began to occur (Figs. 2 and 3a-d). The acceleration of protein degradation occurred at the same time as the beginning of the intense chlorophyll degradation. In the early form, the soluble proteins were degraded in three distinct stages, the beginning and length of which were related to changes in temperature and chlorophyll content (average Pearson correlation coefficients for 2005 and 2008 were 0.79 and 0.98 , respectively, $\mathrm{P} \leq 0.001$ ) (Fig. 1, 2 and $3 \mathrm{a}-\mathrm{b}$ ). In this form, two stages of intense protein degradation were separated by a stage in which the protein level fell slowly. In contrast, the late form was characterised by a relatively constant rate of decrease in the protein content; distinct degradation stages of soluble protein degradation were less apparent, and there was a more stable and constant decrease in the protein content. Protein content in late form was less dependent on temperature fluctuations and was highly related to chlorophyll content (average Pearson correlation coefficients for 2005 and 2008 were 0.32 and 0.98 , respectively, $\mathrm{P} \leq 0.001)$. Similar to the findings with chlorophyll degradation, we observed a significant interaction between soluble and insoluble protein content, and a sudden decrease in temperature change affected these parameters. The time course for insoluble protein degradation was similar to that of soluble proteins in the various phenological forms (the average Pearson correlation coefficient between soluble and insoluble protein contents was 0.99, $\mathrm{P}<0.01$ ). However, a more stable and slower decrease in the insoluble protein concentration was measured in comparison to the soluble protein concentration (Fig. 3c-d).

Protein degradation during leaf senescence resulted in the release of amino acids at a rate that was dependent on the observed proteolysis process. The three phenological forms did not differ in their amino acid content until the beginning of the first stage of protein degradation, i.e., approximately September 3-10 (Fig. 3e-f). Protein degradation at this stage caused an increase of approximately $50 \%$ in the amino acid content of the leaves. The date and extent of the increase differed significantly among the phenological forms $(\mathrm{P}<0.01$ for both 2005 and 2008). Depending on the temperature of the environment and the related protein degradation process, the concentration of amino acids in the leaves increased slowly until approximately October 5-13, i.e., until the beginning of the second phase of protein degradation, when there was a rapid, several-fold increase in the amino acid content of the senescing leaves.

\section{Total nitrogen and $\mathrm{C} / \mathrm{N}$ analysis}

The nitrogen content of the senescing leaves was highest at the beginning of senescence. As with the protein content, the early and intermediate beech form showed a more pronounced stage-related decrease in nitrogen content than late form (Fig. 4). Correlation analysis demonstrated a significant effect of temperature on nitrogen content in senescing leaves. The early, intermediate and late phenological forms of beech were characterised by decreasing Pearson correlation coefficients. For both 2005 and 2008, the average correlation coefficients for the early, intermediate and late forms were $0.96,0.88$ and 0.55 , respectively $(\mathrm{P}<0.05)$. The results demonstrated that the correlation coefficients for the early and late phenological forms differed significantly $(\mathrm{P}=0.045)$. In the early and intermediate forms, the marked decrease in nitrogen content occurred in two stages; the first stage occurred during the period from September 3 to September 10 and the second was from September 18-27 until the end of senescence. The late 

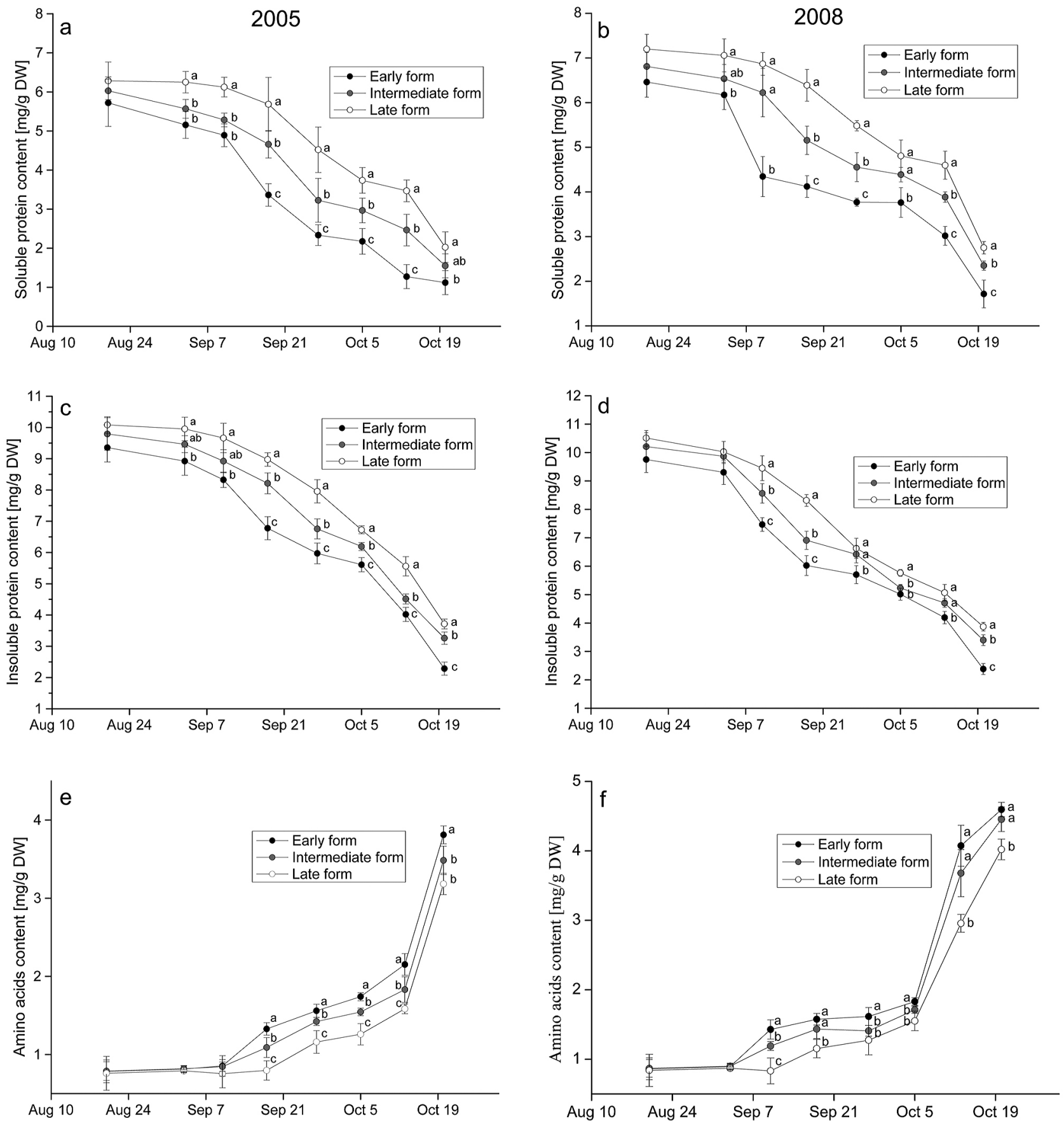

Fig. 3. Changes in the soluble protein (a, b), insoluble protein (c, d) and amino acid (e, f) contents of leaves from different phenological forms of beech trees during autumn senescence. Each point is the mean of 15 measurements $( \pm S D)$. Means denoted by different letters are significantly different at $\mathrm{P}<0.05$

form showed a slow, stable decrease in nitrogen content from the beginning of senescence until approximately September 27 to October 5, after which the nitrogen content continued to decrease rapidly until the end of senescence. During the final stage of the nitrogen content decrease, the early form exhibited the greatest ability to transfer nitrogen to other parts of the plant. As a result of the senescence process, the nitrogen content in the early, intermediate and late forms decreased to $0.84 \%, 0.93 \%$ and $1.03 \%$ of the dry weight, respectively. At the beginning of senescence, the $\mathrm{C} / \mathrm{N}$ ratio was approximately 20 , and it did not differ in the various phenological forms. Over the course of the senescence process, the phenological forms showed an increasing $\mathrm{C} / \mathrm{N}$ ratio. The early form was characterised by significantly higher values of this ratio than the late form $(\mathrm{P}=0.0003, \mathrm{Tab} .1)$. Initially, the $\mathrm{C} / \mathrm{N}$ ratio increased slowly; starting at the beginning of October, it increased very rapidly, reaching significantly different values (averaged for 

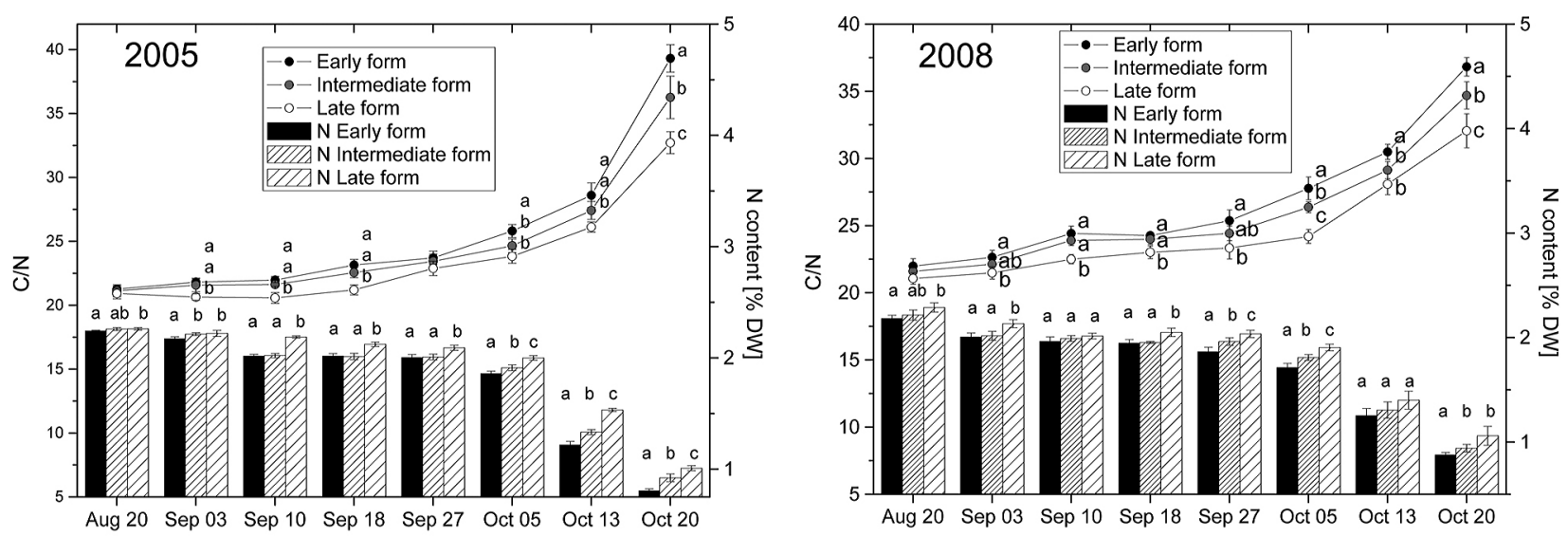

Fig. 4. C/N ratio (\% \%-1 of DW) (lines) and nitrogen content (\% of DW) (columns) in senescing leaves from different phenological forms of beech trees. For each sampling date, the columns followed by different letters were significantly different at $\mathrm{p} \leq 0.05$. Each point is the mean of 15 measurements $( \pm S D)$. Means denoted by different letters are significantly different at $\mathrm{P}<0.05$

2005 and 2008) of $37.5,35$ and 32 for the early, intermediate and late phenological forms, respectively (Fig. 4).

\section{Nitrogen resorption efficiency}

The nitrogen resorption efficiency was calculated for the sampling period, i.e., from August 20 to October 20. The longer period of high temperatures in 2005 resulted in a significantly greater resorption of soluble protein and total nitrogen in all phenological forms relative to the corresponding values obtained in $2008(\mathrm{P} \leq 0.01)$. Insoluble proteins were resorbed to the same degree in 2005 and 2008 (Tab. 2). In both sampling periods, the phenological forms differed significantly in their degrees of resorption of soluble protein, insoluble protein and total nitrogen $(\mathrm{P}<0.001)$. The specimens that began to senesce the earliest showed the highest resorption of nitrogen compounds. The average difference in the resorption efficiency of soluble, insoluble and total protein in the early and late phenological forms was approximately $12.0 \%$, whereas the average difference was $6.8 \%$ for total nitrogen (Tab. 2).

\section{Protease activity}

Senescence was associated with increased proteolytic activity in the beech leaves. The aminopeptidase activity increased most rapidly during the initial stage of senescence; the maximum aminopeptidase activity was present on approximately September 10 in all phenological forms (Fig. 5c). The early form showed significantly greater maximum aminopeptidase activity than the other forms $(\mathrm{P}=0.033$, Tab. 1$)$. A decrease in the activity of this enzyme occurred after September 10; the earlier the phenological form, the greater the decrease. In the late phenological form, the aminopeptidase activity increased during the initial stages of senescence and then remained constant until the end of the senescence process (Fig. 5c). The endopeptidase activity increased more slowly, reaching a maximum between September 27 and October 5, when the leaves were in an advanced stage of senescence (Fig. 5a-b). In the early form, the endopeptidases reached their maximum activity approximately one week earlier than in the late form and showed greater maximum activity. The endopeptidase activity at $\mathrm{pH} 5.7$ was approximately 3 -fold greater than the endopeptidase activity at $\mathrm{pH}$ 7.5. Carboxypeptidase showed a similar increase in

Table 2. Protein and nitrogen resorption efficiency in senescing leaves from different phenological forms of beech trees (percent of protein/nitrogen resorbed)

\begin{tabular}{|c|c|c|c|c|c|c|c|c|}
\hline \multirow{3}{*}{ Nitrogen source } & \multicolumn{4}{|c|}{2005} & \multicolumn{4}{|c|}{2008} \\
\hline & \multicolumn{3}{|c|}{ Phenological form* } & \multirow{2}{*}{$\begin{array}{l}\text { Mean for } \\
\text { phenological } \\
\text { forms** }\end{array}$} & \multicolumn{3}{|c|}{ Phenological form* } & \multirow{2}{*}{$\begin{array}{l}\text { Mean for } \\
\text { phenological } \\
\text { forms** }\end{array}$} \\
\hline & Early & Intermediate & Late & & Early & Intermediate & Late & \\
\hline Soluble protein & $80.4 \pm 2.7$ & $74.3 \pm 2.2$ & $67.8 \pm 2.1$ & $74.2(12.6)$ & $73.5 \pm 2.2$ & $65.5 \pm 1.2$ & $61.8 \pm 1.3$ & $66.9(11.7)$ \\
\hline Insoluble protein & $75.6 \pm 1.4$ & $66.7 \pm 1.1$ & $63.2 \pm 1.7$ & $68.5(12.4)$ & $76.1 \pm 1.0$ & $66.7 \pm 1.0$ & $63.2 \pm 1.2$ & $68.5(12.9)$ \\
\hline Total protein & $77.4 \pm 2.2$ & $69.6 \pm 1.4$ & $64.9 \pm 1.8$ & $70.6(12.5)$ & $74.7 \pm 1.5$ & $66.2 \pm 1.3$ & $62.6 \pm 1.05$ & $67.8(12.1)$ \\
\hline Total nitrogen & $64.1 \pm 1,2$ & $59.2 \pm 1,6$ & $55.4 \pm 0.6$ & $59.6(8.7)$ & $59.9 \pm 0.9$ & $57.5 \pm 0.6$ & $53.7 \pm 0.9$ & $57.0(6.2)$ \\
\hline
\end{tabular}

\footnotetext{
* All average values for the phenological forms were significantly different at $\mathrm{P}<0.001$
}

** Differences between the early and late phenological forms are given in parentheses 

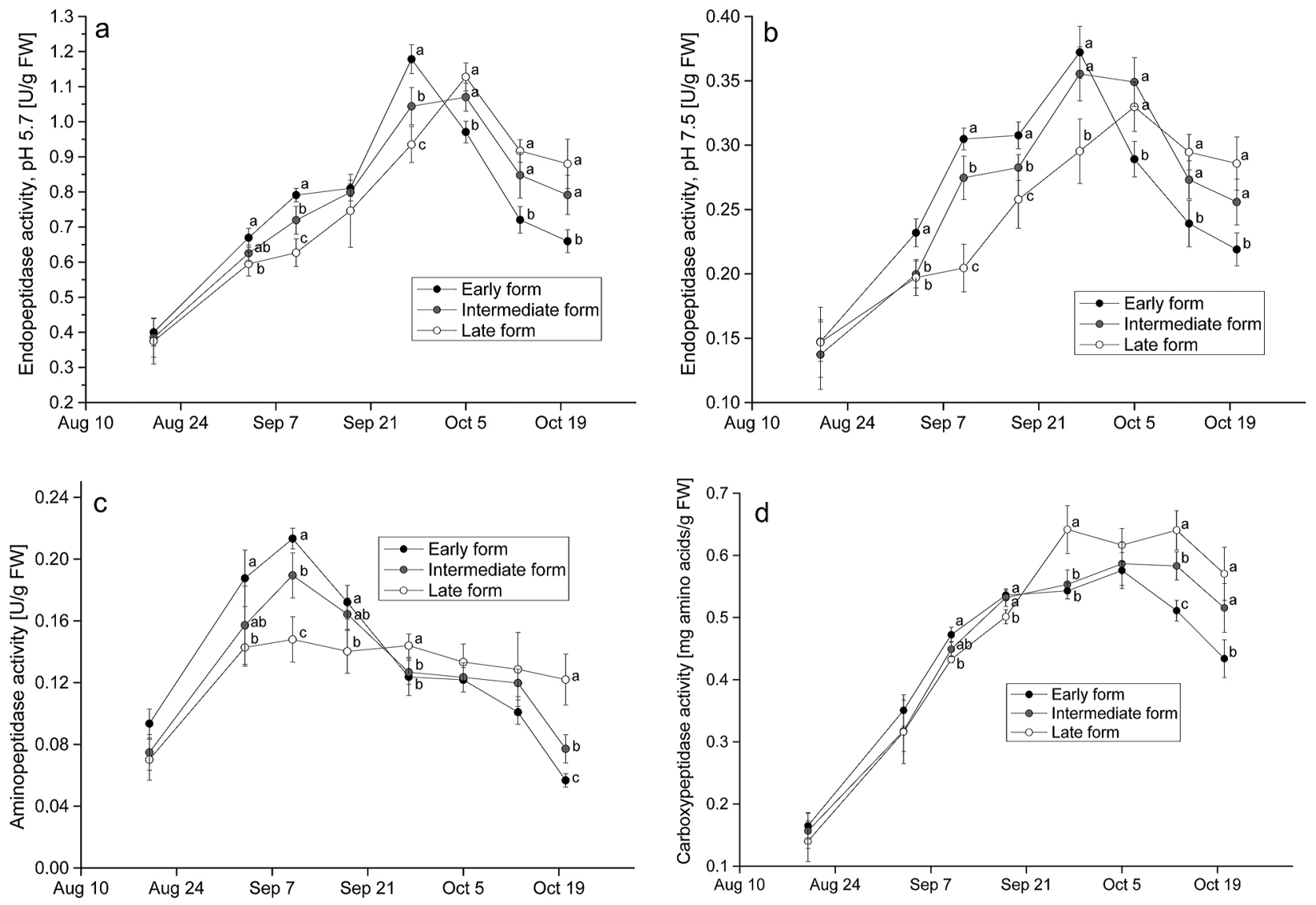

Fig. 5. Changes in the endopeptidase activity at pH 5.7 (a), endopeptidase activity at pH 7.5 (b), aminopeptidase activity (c) and carboxypeptidase activity (d) in leaves from different phenological forms of beech trees during autumn senescence. The peptidase activities were analysed in 2008. Each point is the mean of 15 measurements $( \pm S D)$. Means denoted by different letters are significantly different at $\mathrm{P}<0.05$

activity in all phenological forms until approximately September 18. After this date, the activity of this enzyme increased more in the late form, remained stable for approximately 2 weeks and then decreased slightly. The early and intermediate forms showed similar durations of maximum carboxypeptidase activity, but the level of activity was lower in these forms (Fig. 5d).

\section{Correlation analysis}

A correlation analysis was performed between protease activity and chlorophyll, nitrogen and nitrogen-containing compounds, such as soluble and insoluble proteins and amino acids content. Proteolytic enzymes exhibited increased activity, the extent of which was connected with the enzyme type and phenological form. The maximum individual protease activities were achieved the earliest for aminopeptidase, followed by endopeptidase and carboxypeptidase (Fig. 5a-d). Examining the dates on which the samples were collected confirmed that protease activity was connected with the temperature. Aminopeptidase reached its peak activity just prior to a sud- den drop in the temperature (Fig. 1b and 5c). Conversely, endo- and carboxypeptidase reached their maximum activities after the minimum temperature decreased to its lowest level, i.e., approximately September 27 (Fig. 1b and 5a, b and d). A strong correlation was observed between protease activity and the biochemical markers connected with the course and the rate of leaf senescence (based on chlorophyll, proteins and amino acid contents) from the onset of senescence until maximum proteolytic activity was reached (Tab. 3). In the earlier beech specimens, the activities of the individual peptidase types decreased more markedly (Fig. 1b and d).

\section{Discussion}

This study highlights the significant relationship between autumn phenological features in beech trees and the efficiency of nitrogen remobilisation during leaf senescence in 2005 and 2008. Two different years were chosen to compare the dynamics of protein degradation to free amino acids and the proteolytic activity of beech leaves. The beech phenological forms 
Table 3. Pearson correlation coefficients between the protease activity and biochemical characteristics of senescing leaves from different phenological forms of beech trees. The data represent correlations based on the period that was characterised by increased enzyme activity, i.e., from August 20, 2008 to September 10, 2008 for aminopeptidase and from August 20, 2008 to September 27, 2008 for endopeptidase and carboxypeptidase

\begin{tabular}{|c|c|c|c|c|c|c|}
\hline Peptidase type & Total chlorophyll & $\begin{array}{c}\text { Soluble } \\
\text { proteins }\end{array}$ & $\begin{array}{l}\text { Insoluble } \\
\text { proteins }\end{array}$ & Amino acids & Nitrogen & $\mathrm{C} / \mathrm{N}$ \\
\hline \multicolumn{7}{|c|}{ Early form } \\
\hline Aminopeptidase & -0.946 & -0.849 & -0.836 & 0.727 & -0.967 & 0.902 \\
\hline Endopeptidase, pH 5.7 & $-0.940^{*}$ & $-0.926^{*}$ & $-0.894^{*}$ & $0.882^{*}$ & $-0.924^{*}$ & $0.957^{*}$ \\
\hline Endopeptidase, pH 7.5 & $-0.931^{*}$ & $-0.946^{*}$ & $-0.919 *$ & $0.902 *$ & $-0.991^{* *}$ & $0.974^{* *}$ \\
\hline Carboxypeptidase & $-0.894^{*}$ & $-0.917^{*}$ & $-0.907^{*}$ & $0.881^{*}$ & $-0.982^{* *}$ & $0.934^{*}$ \\
\hline \multicolumn{7}{|c|}{ Intermediate form } \\
\hline Aminopeptidase & -0.985 & -0.983 & -0.872 & 0.814 & -0.977 & 0.914 \\
\hline Endopeptidase, pH 5.7 & $-0.979 * *$ & $-0.953^{*}$ & $-0.947^{*}$ & $0.926^{*}$ & $-0.890^{*}$ & $0.968 * *$ \\
\hline Endopeptidase, pH 7.5 & $-0.957^{*}$ & $-0.926^{*}$ & $-0.947^{*}$ & $0.926^{*}$ & $-0.933^{*}$ & $0.985^{* *}$ \\
\hline Carboxypeptidase & $-0.888^{*}$ & -0.867 & $-0.915^{*}$ & $0.898^{*}$ & $-0.986^{* *}$ & $0.963^{* *}$ \\
\hline \multicolumn{7}{|c|}{ Late form } \\
\hline Aminopeptidase & -0.987 & -0.807 & -0.847 & 0.301 & -0.925 & 0.649 \\
\hline Endopeptidase, pH 5.7 & $-0.975^{* *}$ & $-0.912^{*}$ & $-0.950^{*}$ & $0.882^{*}$ & $-0.919 *$ & $0.933^{*}$ \\
\hline Endopeptidase, pH 7.5 & $-0.959^{*}$ & $-0.918^{*}$ & $-0.962^{* *}$ & $0.900^{*}$ & $-0.904^{*}$ & $0.946^{*}$ \\
\hline Carboxypeptidase & $-0.947^{*}$ & -0.874 & $-0.929 *$ & 0.818 & $-0.968^{* *}$ & $0.921^{*}$ \\
\hline
\end{tabular}

* ** significant at $\mathrm{P}<0.05$ and $\mathrm{P}<0.01$, respectively

exhibited different sensitivities in their biochemical and, thus, phenological processes, including the sensitivity of nitrogen metabolism to temperature fluctuation during autumn leaf senescence.

The dates of the leaf senescence phases depended on the phenological form of the specimens and the temperature during a given vegetative period. The photoperiod and temperature are the most important abiotic factors influencing leaf senescence (Delpierre et al. 2009; Estrella and Menzel 2006). However, the photoperiod appears to have a smaller effect on the onset of beech leaf senescence than the temperature, as the date of the beginning of senescence depends on the temperature during the individual vegetative period. In F. sylvatica, the rate of this process is highly correlated with temperature, which has been shown to regulate the course and rate of leaf colouring and leaf fall (Thomas and Stoddart 1980; Schuster et al. 2013b; Škvareninová and Snopková 2011). The senescence of beech leaves is generally delayed by higher temperatures, with a response rate of $5-7$ days $/{ }^{\circ} \mathrm{C}$ (Menzel and Fabian 1999; Schuster et al. 2013a). In the current study it appears that not only the maximal value of temperature but also the date of any sudden drop in temperature is critical to inducing the biochemical events leading to leaf senescence. The effect of temperature on the rate of leaf senescence was similar to that found in previous studies, because the difference between the average temperatures for the two examined periods was $0.7^{\circ} \mathrm{C}$, which caused a delay of approximately 7 days at the beginning of leaf senescence in 2005. In the studied years, the temperature affected the contents of chlorophyll, soluble and insoluble protein, amino acids and nitrogen and the $\mathrm{C} / \mathrm{N}$ ratio.
In trees, internal nitrogen cycling occurs via assimilation, re-translocation and storage. These processes are seasonally programmed and closely linked to tree phenology (Wang et al. 2013). The nitrogen economy of trees depends on the leaf lifespan and the efficiency of nitrogen resorption from senescing leaves (Yasumura et al. 2002). The results presented here showed the effect of the phenological form on the rate of leaf senescence and, thus, on the course of nitrogen compounds resorption. During both examined periods, the specimens that began to senesce earlier remobilised a greater mass of nitrogen compounds, irrespective of the thermal conditions. These data indicate that the decrease in nitrogen content reflects a greater nitrogen resorption efficiency in leaves that senesce longer (Niinemets and Tamm 2005). The re-translocation and storage of nitrogen compounds in the perennial organs of the beech trees caused changes in the leaf $\mathrm{C} / \mathrm{N}$ ratio. The data obtained in the present study showed differences in the $\mathrm{C} / \mathrm{N}$ ratio between beech individuals that differed over the course of autumn leaf phenology. In August, this ratio was relatively low (approximately 20) and comparable across phenological forms, but it increased almost two-fold at the beginning of leaf fall. These results are consistent with data collected from 90 -year-old trees that were previously presented by Wang and others (2013). However, in the present study, the quickest increase in the $\mathrm{C} / \mathrm{N}$ ratio was observed in specimen of the early phenological form, which was characterised as having the highest nitrogen recycling ratio.

The date of senescence onset of leaves affects tree growth because it is associated with the remobilisation of nutrients, particularly nitrogen (Lim et al. 
2007). Thus, prolonged autumn senescence, which is characteristic of early phenotypes, results in the increased storage of assimilates. Vitasse et al. (2009) showed that the senescence date of beech trees significantly influences the growth rate. Additionally, Chmura and Rożkowski (2002) suggested that the times of bud burst and growth cessation could influence the survival and growth performance of beech trees. It should be noted, however, that unfavourable climatic conditions can cause incomplete nutrient remobilisation as a result of frost damage to functional leaves (Keskitalo et al. 2005). Dyckmans and Flessa (2001) reported that the contribution of the previous year's nitrogen to new leaf formation in the spring was approximately $15 \%$ and that beech growth is strongly determined by the availability of internal nitrogen stores, whereas the current nitrogen supply is less important.

The need for protein degradation during the remobilisation processes causes an increase in the plant's peptidase activity at the onset of leaf senescence and during its later phases. The hydrolysis of proteins into free amino acids depends on the action of different types of peptidases and is related to the rate of senescence (Hortensteiner and Feller 2002; Nooden et al. 1997; Buchanan-Wollaston et al. 2003). The results of other protein degradation studies suggest that senescence is the primary process responsible for the dramatic increase in remobilised nitrogen during leaf senescence. The use of remobilised nitrogen requires the conversion of proteins into amino acids, the transport of amino acids from source tissues to sink tissues via the phloem and the subsequent synthesis of proteins (Hayashi and Chino 1990). In the current study, the amino acid content of the senescing beech leaves was found to increase slowly until the beginning of October. It was inferred that during the early senescence period, almost all of the free amino acids from protein degradation were transported to perennial tissues and used to synthesise storage proteins. However, a sudden increase in the amino acid content of the plant tissues occurred at the end of leaf senescence. The increased amino acid content was likely associated with protein degradation by endo- and carboxypeptidases and with the production of amino acids, which could not be exported due to sieve tube occlusion (Rolland et al. 2006).

Relationships were found among enzyme activity, peptidase type and phenological form of the beech tree. The sequence in which various peptidase types reached their maximal activities was related to their cellular location, their function in protein degradation and the ways in which their activity was regulated. While total aminopeptidase activity diminishes early during senescence, endopeptidase and carboxypeptidase activities increase until the final senescence stages, which take place after the cell membranes are damaged (Masclaux et al. 2001; Yamada et al. 2001). The data presented here clearly illustrate the differences between phenological beech forms with respect to changes in peptidase activities and their maximum levels. With the exception of carboxypeptidase, all enzymes exhibited greater maximum activity in the early phenological form than in the late form. The study confirmed that endo- and carboxypeptidase activity were associated with the biochemical features of the senescing leaves from August 20 to approximately September 27, i.e., until the temperature decreased. During the final stage of senescence, the decrease in the minimum temperature and the location of individual peptidase types and their functional properties caused a corresponding decrease in the proteolytic activity in the leaves. The early phenological form was characterised by the longest period of senescence and nitrogen remobilisation at higher temperatures, which caused elongation of the senescing process in this form and the highest efficiency of nitrogen remobilisation. The fact that the decrease in the minimum temperature had the greatest impact on early-senescing beech individuals indicates that the early-senescing form exhibits the greatest sensitivity to the drop in temperature and confirms that temperature has a decisive effect on the course of beech leaf senescence.

In conclusion, our results show that the phenological forms of beech trees differ in terms of their protein degradation and nitrogen remobilisation efficiency dynamics in senescing leaves. By using individuals that differed in their autumn senescence times during two years when there were different temperature fluctuations, it was possible to determine the effects of the length of leaf senescence and the field temperature course on the nitrogen resorption efficiency. The relationship between the senescence course of beech leaves and their proteolytic activity and nitrogen recycling was shown. The allocation of nitrogen affects the ecophysiology of the phenological forms of beech, including photosynthesis and nutrient storage in the leaves. Foliar resorption can potentially supply part of the nitrogen needed for new foliage growth in the following year, thus causing tight nutrient cycling in the ecosystem. However, it should be emphasised that leaf senescence is a complex process that depends on many biochemical and molecular as well as environmental factors. It will be necessary to investigate the different underlying bases of proteolytic activity connected with nitrogen remobilisation during leaf senescence in beech. This information will help us better understand the physiological differences between the phenological forms of beech. 


\section{References}

Aerts R. 1996. Nutrient resorption from senescing leaves of perennials: are there general patterns? Journal of Ecology 84: 597-608. http://dx.doi. org/10.2307/2261481

Bradford M.M. 1976. A rapid and sensitive method for the quantitation of microgram quantities of protein utilizing the principle of protein-dye binding. Analytical Biochemistry 72: 248-254. http:// dx.doi.org/10.1016/0003-2697(76)90527-3

Brouquisse R., Masclaux C., Feller U., Raymond P. 2001. Protein hydrolysis and nitrogen remobilization in plant life and senescence. In: Plant nitrogen. Lea P., Morot-Gaudry J.F. (eds.). Springer, Berlin, pp. 275-293. http://dx.doi.org/10.1007/978-3662-04064-5 11

Buchanan-Wollaston V., Earl S., Harrison E., Mathas E., Navabpour S., Page T., Pink D. 2003. The molecular analysis of leaf senescence-a genomics approach. Plant Biotechnology Journal 1: 3-22. http://dx.doi.org/10.1046/j.14677652.2003.00004.x

Chmura D.J., Rożkowski R. 2002. Variability of beech provenances in spring and autumn phenology. Silvae Genetica 51: 123-127.

Coleman G.D., Englert J.M., Chen T.H.H., Fuchigami, L.H. 1993. Physiological and environmental requirements for poplar (Populus deltoides) bark storage protein degradation. Plant Physiology 102: 53-59. http://dx.doi.org/10.1104/pp.102.1.53

Cooke J.E.K., Weih M. 2005. Nitrogen storage and seasonal nitrogen cycling in Populus: bridging molecular physiology and ecophysiology. New Phytologist 167: 19-30. http://dx.doi.org/10.1111/ j.1469-8137.2005.01451.x

Cote B., Fyles J.W., Djalilvand H. 2002. Increasing $\mathrm{N}$ and $\mathrm{P}$ resorption efficiency and proficiency in northern deciduous hardwoods with decreasing foliar $\mathrm{N}$ and $\mathrm{P}$ concentrations. Annals Forest Science 59: 275-281. http://dx.doi.org/10.1051/forest:2002023

Couturier J., Doidy J., Guinet F., Wipf D., Blaudez D., Chalot M. 2010. Glutamine, arginine and the amino acid transporter Pt-CAT11 play important roles during senescence in poplar. Annals of Botany 105: 1159-1169. http://dx.doi.org/10.1093/ aob/mcq047

Delpierre N., Dufrene E., Soudani K., Ulrich E., Cecchini S., Boe J., Francois C. 2009. Modelling interannual and spatial variability of leaf senescence for three deciduous tree species in France. Agricultural and Forest Meteorology 149: 938-948. http:// dx.doi.org/10.1016/j.agrformet.2008.11.014

Diaz C., Purdy S., Christ A., Morot-Gaudry J.F., Wingler A., Masclaux-Daubresse C. 2005. Characterization of markers to determine the extent and variability of leaf senescence in Arabidopsis. A metabolic profiling approach. Plant Physiology 138: 898-908. http://dx.doi.org/10.1104/ pp.105.060764

Dolnicki A., Kraj W. 2001. Leaf morphology and the dynamics of frost-hardiness of shoots in two phenological forms of European beech (Fagus sylvatica L.) from Southern Poland. Electronic Journal of Polish Agricultural Universities 4, (http://www.ejpau.media.pl/volume4/issue2/forestry/art-01.html).

Duchesne L., Ouimet R., Camire C., Houle D. 2001. Seasonal nutrient transfers by foliar resorption, leaching, and litter fall in a northern hardwood forest at Lake Clair Watershed, Quebec, Canada. Canadian Journal of Forest Research 31: 333-344. http://dx.doi.org/10.1139/x00-183

Dyckmans J., Flessa H. 2001. Influence of tree internal $\mathrm{N}$ status on uptake and translocation of $\mathrm{C}$ and $\mathrm{N}$ in beech: a dual C-13 and N-15 labeling approach. Tree Physiology 21: 395-401. http:// dx.doi.org/10.1093/treephys/21.6.395

Estrella N., Menzel A. 2006. Responses of leaf colouring in four deciduous tree species to climate and weather in Germany. Climate Research 32: 253-267. http://dx.doi.org/10.3354/cr032253

Fang J., Lechowicz M.J. 2006. Climatic limits for the present distribution of beech (Fagus L.) species in the world. Journal of Biogeography 33: 1804-1819. http://dx.doi.org/10.1111/j.13652699.2006.01533.x

Feller U., Fischer A. 1994. Nitrogen-Metabolism in Senescing Leaves. Critical Reviews in Plant Sciences 13: 241-273. http://dx.doi. org/10.1080/07352689409701916

Fracheboud Y., Luquez V., Bjorken L., Sjodin A., Tuominen H., Jansson S. 2009. The control of autumn senescence in European aspen. Plant Physiology 149: 1982-1991. http://dx.doi. org/10.1104/pp.108.133249

Gan S. 2003. Mitotic and postmitotic senescence in plants. Science of Aging Knowledge Environment 38: RE7.

Gan S.S., Amasino R.M. 1997. Making sense of senescence. Molecular genetic regulation and manipulation of leaf senescence. Plant Physiology 113: 313-319.

Guiboileau A., Sormani R., Meyer C., Masclaux-Daubresse C. 2010. Senescence and death of plant organs: Nutrient recycling and developmental regulation. Comptes Rendus Biologies 333: 382-391. http://dx.doi.org/10.1016/j. crvi.2010.01.016

Hayashi H., Chino M. 1990. Chemical-composition of phloem sap from the uppermost internode of the rice plant. Plant and Cell Physiology 31: 247251. 
Himelblau E., Amasino R.M. 2001. Nutrients mobilized from leaves of Arabidopsis thaliana during leaf senescence. Journal of Plant Physiology 158: 1317-1323. http://dx.doi.org/10.1078/01761617-00608

Hortensteiner S., Feller U. 2002. Nitrogen metabolism and remobilization during senescence. Journal of Experimental Botany 53: 927-937. http:// dx.doi.org/10.1093/jexbot/53.370.927

Howe G.T., Aitken S.N., Neale D.B., Jermstad K.D., Wheeler N.C., Chen T.H.H. 2003. From genotype to phenotype: unraveling the complexities of cold adaptation in forest trees. Canadian Journal of Botany 81: 1247-1266. http://dx.doi. org/10.1139/b03-141

Huffaker R.C. 1990. Proteolytic activity during senescence of plants. New Phytologist 116: 199-231. http://dx.doi.org/10.1111/j.1469-8137.1990. tb04710.x

Keskitalo J., Bergquist G., Gardestrom P., Jansson S. 2005. A cellular timetable of autumn senescence. Plant Physiology 139: 1635-1648. http://dx.doi. org/10.1104/pp.105.066845

Kraj W., Grad B. 2013. Seasonal dynamics of photosynthetic pigment, protein and carbohydrate contents in Pinus sylvestris L. seedlings inoculated with Hebeloma crustuliniforme and Laccaria bicolor. Journal of Plant Nutrition 36: 633-650. http://dx.doi.org/10.1080/01904167.2012.754035

Lichtenthaler H.K., Wellburn A.R. 1983. Determinations of total carotenoids and chlorophylls a and $\mathrm{b}$ of leaf extracts in different solvents. Biochemical Society Transactions 11: 591-592.

Lim P.O., Kim H.J., Nam H.G. 2007. Leaf senescence. Annual Review of Plant Biology 58: 115-136. http://dx.doi.org/10.1146/annurev.arplant.57.032905.105316

Lin J.F., Wu S.H. 2004. Molecular events in senescing Arabidopsis leaves. Plant Journal 39: 612-628. http://dx.doi.org/10.1111/j.1365313X.2004.02160.X

Marschner H. 1995. Mineral nutrition of higher plants. Academic Press, London.

Masclaux C., Quillere I., Gallais A., Hirel B. 2001. The challenge of remobilisation in plant nitrogen economy. A survey of physio-agronomic and molecular approaches. Annals of Applied Biology 138: 6981. http://dx.doi.org/10.1111/j.1744-7348.2001. tb00086.x

Menzel A., Fabian P. 1999. Growing season extended in Europe. Nature 397: 659. http://dx.doi. org/10.1038/17709

Millard P., Grelet G.-A. 2010. Nitrogen storage and remobilization by trees: ecophysiological relevance in a changing world. Tree Physiology 30: 1083-1095. http://dx.doi.org/10.1093/treephys/ tpq042
Niinemets U., Tamm U. 2005. Species differences in timing of leaf fall and foliage chemistry modify nutrient resorption efficiency in deciduous temperate forest stands. Tree Physiology 25: 1001-1014. http://dx.doi.org/10.1093/treephys/25.8.1001

Nooden L.D., Guiamet J.J., John I. 1997. Senescence mechanisms. Physiology Plantarum 101: 746-753. http://dx.doi.org/10.1111/j.1399-3054.1997. tb01059.x

Paule L. 1995. Gene conservation in European beech (Fagus sylvatica L.). Forest Genetics 2: 161-170.

Quirino B.F., Noh Y.S., Himelblau E., Amasino R.M. 2000. Molecular aspects of leaf senescence. Trends in Plant Science 5: 278-282. http://dx.doi. org/10.1016/S1360-1385(00)01655-1

Rennenberg H., Kreutzer K., Papen H., Weber P. 1998. Consequences of high loads of nitrogen for spruce (Picea abies) and beech (Fagus sylvatica) forests. New Phytologist 139: 71-86. http://dx.doi. org/10.1046/j.1469-8137.1998.00181.x

Rolland F., Baena-Gonzalez E., Sheen J. 2006. Sugar sensing and signaling in plants: Conserved and novel mechanisms. Annual Review of Plant Biology 57: 675-709. http://dx.doi.org/10.1146/ annurev.arplant.57.032905.105441

Roulin S., Feller U. 1998. Light-independent degradation of stromal proteins in intact chloroplasts isolated from Pisum sativum L. leaves: requirement for divalent cations. Planta 205: 297-304. http:// dx.doi.org/10.1007/s004250050324

Schuster C., Estrella N., Menzel A. 2013a. Shifting and extension of phenological periods with increasing temperature along elevational transects in southern Bavaria. Plant Biology 16: 332-344. http://dx.doi.org/10.1111/plb.12071

Schuster C., Kirchner M., Jakobi G., Menzel A. 2013b. Frequency of inversions affects senescence phenology of Acer pseudoplatanus and Fagus sylvatica. International Journal of Biometeorology 58: 485-498. http://dx.doi.org/10.1007/s00484013-0709-0

Smart C.M. 1994. Gene expression during leaf senescence. New Phytologist 126: 419-448. http:// dx.doi.org/10.1111/j.1469-8137.1994.tb04243.x

Sokal R.R., Rohlf F.J. 1995. Biometry: the principles and practice of statistics in biological research. W.H. Freeman and Company, New York.

Stachak A. 1965. Fenologia buka zwyczajnego na tle warunków siedliskowych w Puszczy Bukowej pod Szczecinem w latach 1957-1961. Szczecińskie Towarzystwo Naukowe, Wydział Nauk Przyr.-Roln., Szczecin, pp. 1-100.

Škvareninová J., Snopková Z. 2011. The development of phenological stages of European beech (Fagus sylvatica L.) in Slovakia during the period of 1996-2010. In: Šiška B., Hauptvogl M., Eliašová M. (eds.). Bioclimate: Source and Limit of Social 
Development International Scientific Conference, 6-9 September 2011, Topolčianky, Slovakia.

Thomas H., Stoddart J.L. 1980. Leaf senescence. Annual Review of Plant Physiology 31: 83-111. http://dx.doi.org/10.1146/annurev. pp.31.060180.000503

Vitasse Y., Delzon S., Bresson C.C., Michalet R., Kremer A. 2009. Altitudinal differentiation in growth and phenology among populations of temperate-zone tree species growing in a common garden. Canadian Journal of Forest Research 39: 1259-1269. http://dx.doi.org/10.1139/X09-054

Wang L., Ibrom A., Korhonen J.F.J., Arnoud Frumau K.F., Wu J., Pihlatie M., Schjoerring J.K. 2013. Interactions between leaf nitrogen status and longevity in relation to $\mathrm{N}$ cycling in three contrasting European forest canopies. Biogeosciences 10: 999-1011. http://dx.doi.org/10.5194/bg-10-9992013

Yamada K., Matsushima R., Nishimura M., Hara-Nishimura I. 2001. A slow maturation of a cysteine protease with a granulin domain in the vacuoles of senescing Arabidopsis leaves. Plant Physiology 127: 1626-1634. http://dx.doi. org/10.1104/pp.010551

Yang L., Mickelson S., See D., Blake T.K., Fischer A.M. 2004. Genetic analysis of the function of major leaf proteases in barley (Hordeum vulgare L.) nitrogen remobilization. Journal of Experimental Botany 55: 2607-2616. http://dx.doi.org/10.1093/ jxb/erh267

Yasumura Y., Hikosaka K., Matsui K., Hirose T. 2002. Leaf-level nitrogen-use efficiency of canopy and understorey species in a beech forest. Functional Ecology 16: 826-834. http://dx.doi.org/10.1046/ j.1365-2435.2002.00691.x

Yokoyama S., Hiramatsu J. 2003. A modified ninhydrin reagent using ascorbic acid instead of potassium cyanide. Journal of Bioscience and Bioengineering 95: 204-205. http://dx.doi.org/10.1016/ S1389-1723(03)80131-7 